\title{
A Questionnaire Based Study on Awareness of Students in Internship Training or Final Year Across 3 Disciplines Regarding Inter-Professional Educcation - A Descriptive Cross Sectional Study
}

Renuka $\mathbf{S}^{*}$ and Gheena S

Department of Oral Pathology, Saveetha Dental College and Hospitals, Chennai, Tamil Nadu, India

\begin{abstract}
Aim: The aim of this study is to evaluate the awareness among internship students regarding inter-professional Educcation.

Objective: Questionnaire will be devised and administered to students of medical, dental and nursing in final year and internship training.

Background: Inter-professional Educcation (IPE) is an important facet for health professionals because it will benefit them while working along with different professionals in their particular work areas. All health care professionals should be Educcated about inter-professional skills for better communication with other health professionals. Good communication and interaction skills will enhance the quality of treatment and will result in enhanced patient satisfaction.

Reason: Proper inter-professional Educcation is of utmost importance for quality treatment and enhanced patient satisfaction. The main reason of this study is to instil awareness in internship students about inter-professional Educcation and its benefits in their career.
\end{abstract}

Keywords: Inter-professional Educcation; Communication; Awareness; Internship; Students

\section{Introduction}

IPE refers to occasions when students from two or more professions in health and social care learn together during all or part of their professional training with the object of cultivating collaborative practice [1] for providing patient-centred care. IPE plays an important role in health care. Good communication between health care professionals is important for both health professionals and patients. Good communication between health care professionals will enhance the positive relationship between professionals and also helps in quality treatment for the patients. Recent studies show that many patients are benefited from respectful communication with health care professionals, which will enhance the patient's satisfaction [2]. Recent evidence shows that students in various IPE initiatives had positive changes in their attitudes, knowledge, skills and greater level of interactivity between different professionals during IPE training [3-5]. Inter-collegial communication has many potential benefits during practice by increasing job satisfaction and flexibility. Stress and work place tension rEducces when health care personnel work together as a team. The importance of IPE emerged from the need for health care team members to provide high-quality care in the most collaborative and competent way [6]. Each member of a health care team need to know about the role of other professionals for good communication and for quality practice. The importance of intercollegial communication can be mostly seen in surgery ward. IPE pays more attention towards team work. IPE effectively teaches the students about the role of other professions and to change the attitude of the students from one profession towards other professionals. The aim of this study is to identify whether students from medical, dental and nursing are aware about inter professional Educcation when in their final year and internship training.

\section{Materials and Methods}

This is a questionnaire based study on the awareness of inter- professional Educcation among students in internship training. The participants include students of medical, dental and nursing during their final year and internship training from various colleges. The questionnaire is filled in paper and pen method. After the data collection, statistical measurements are done with Chi-square test. Data is collected from 80 participants of each profession during their final year and internship under the supervision of dental students.

The questions mentioned in the Appendix 1 have been asked to the medical, dental and nursing students during their final year and internship through the questionnaire. The answers were marked according to their knowledge. All the fifteen questions are of yes or no type. The IRB (Institutional Review Board) protocol number for this study is STP/16SDIIBDS52.

\section{Results}

This study includes total 240 participants of medical, dental and nursing students from different colleges during their final year and internship training. Among 80 students from each profession $37.5 \%$ interns and $62.5 \%$ final year from medical, $60 \%$ interns and $40 \%$ final year from dental and $100 \%$ final year from nursing $(\mathrm{p}<0.001)$ participated which is tabulated in Table 1.

General awareness about Inter-professional Educcation in the

*Corresponding author: Renuka S, Saveetha Dental College and Hospitals, No. 162, Poonamalle High Road, Chennai-600 077, Tamil Nadu, India, Tel: +919551200126; E-mail: renuka2602@gmail.com

Received August 02, 2016; Accepted September 12, 2016; Published September 20, 2016

Citation: Renuka S, Gheena S (2016) A Questionnaire Based Study on Awareness of Students in Internship Training or Final Year Across 3 Disciplines Regarding Inter-Professional Educcation - A Descriptive Cross Sectional Study. J Health Educ Res Dev 4: 191. doi: 10.4172/2380-5439.1000191

Copyright: $\odot 2016$ Renuka S, et al. This is an open-access article distributed unde the terms of the Creative Commons Attribution License, which permits unrestricted use, distribution, and reproduction in any medium, provided the original author and source are credited. 
Citation: Renuka S, Gheena S (2016) A Questionnaire Based Study on Awareness of Students in Internship Training or Final Year Across 3 Disciplines Regarding Inter-Professional Educcation - A Descriptive Cross Sectional Study. J Health Educ Res Dev 4: 191. doi: 10.4172/23805439.1000191

Page 2 of 7

population of 240 is $84.2 \%$. Students were aware about the meaning of IPE and $15.8 \%$ were not aware about it completely. Among $84.2 \%$ students, $87.5 \%$ are from medical, $86.3 \%$ are from dental and $78.8 \%$ from nursing are aware about inter-professional Educcation $(\mathrm{p}=0.261)$. In comparison between years of study, $88.5 \%$ are aware among interns and $82.1 \%$ are aware among final year $(\mathrm{p}=0.206)$. Among medical profession, $87.5 \%$ of interns and final year were aware about IPE and $12.5 \%$ were not $(\mathrm{p}=0.383)$. Among dental profession, $86.3 \%$ from interns and final year were aware and $13.8 \%$ were not $(\mathrm{p}=0.085)$. Among interns, $83.3 \%$ from medical, $91.7 \%$ from dental were aware about inter-professional Educcation $(\mathrm{p}=0.262)$. Among final years, $90 \%$ from medical, $78.1 \%$ from dental and $78.8 \%$ from nursing were aware $(\mathrm{p}=0.215)$.

$84.2 \%$ of the population think that IPE is essential in curriculum. In that population, $63.7 \%$ from medical, $75 \%$ from dental and $100 \%$ from nursing states that IPE is essential in curriculum $(p<0.001)$ and $83.8 \%$ from medical, $83.8 \%$ from dental and $98.8 \%$ from nursing think that it is essential especially during internship $(\mathrm{p}=0.002)$. On comparing the year of study among professionals, $79.5 \%$ and $84.6 \%$ interns felt that it is essential in curriculum during internship training. $79.6 \%$ and $90.7 \%$ final year students' also felt that it is important during their internship $(\mathrm{p}=0.980)(\mathrm{p}=0.160)$. Among medical professionals, $63.7 \%$ feels that IPE is important in curriculum $(\mathrm{p}=0.167)$ and $83.8 \%$ feels that IPE plays a vital role during internship $(\mathrm{p}=0.584)$. Among dental professionals, $75 \%(\mathrm{p}=0.035)$ feels that IPE is important in curriculum, $83.8 \%(\mathrm{p}=0.902)$ believe that it is essential during internship training. Among interns, 79.5\% from medical and dental students feels that IPE is important in curriculum ( $\mathrm{p}=0.287)$ and $84.6 \%$ medical and dental feels that it is important only during internship training $(\mathrm{p}=0.691)$. Among final years, $79.6 \%$ from medical, dental and nursing students feels that IPE is important in curriculum $(\mathrm{p}<0.001)$ and $90.7 \%$ medical, dental and nursing students feels that it is important only during internship training ( $\mathrm{p}=0.002$ ). 61.3\% medical, 62.5\% dental and $97.5 \%$ nursing students think that it is important to be taught communication skills together with other professionals $(\mathrm{p}<0.001)$ and $67.5 \%$ medical, $85 \%$ dental and $98.8 \%$ nursing students feels that communication skills that are related to patients safety should be taught together with other

\begin{tabular}{|c|c|c|c|c|c|c|c|}
\hline & & \multicolumn{6}{|c|}{ Professions } \\
\hline & & \multicolumn{2}{|c|}{ Medical } & \multicolumn{2}{|c|}{ Dental } & \multicolumn{2}{|c|}{ Nursing } \\
\hline & & Yes & No & Yes & No & Yes & No \\
\hline 1. & $\begin{array}{l}\text { Are you aware about Inter-professional } \\
\text { Educcation (IPE) }\end{array}$ & $70(87.5 \%)$ & $10(12.5 \%)$ & $69(86.3 \%)$ & $11(13.8 \%)$ & $63(78.8 \%)$ & $17(21.3 \%)$ \\
\hline 2 & $\begin{array}{l}\text { Do you think IPE is essential in } \\
\text { curriculum? }\end{array}$ & $51(63.7 \%)$ & $29(36.3 \%)$ & $60(75 \%)$ & $20(25 \%)$ & $80(100 \%)$ & 0 \\
\hline 3. & $\begin{array}{l}\text { Do you think that IPE is important } \\
\text { during internship }\end{array}$ & $67(83.8 \%)$ & $13(16.3 \%)$ & $67(83.8 \%)$ & $13(16.3 \%)$ & $79(98.8 \%)$ & $1(1.3 \%)$ \\
\hline 4. & $\begin{array}{l}\text { Do you think learning with other health } \\
\text { care students would be difficult to } \\
\text { manage? }\end{array}$ & $43(53.8 \%)$ & $37(46.3 \%)$ & $34(42.5 \%)$ & $46(57.5 \%)$ & $43(57.8 \%)$ & $37(46.3 \%)$ \\
\hline 5. & $\begin{array}{l}\text { Do you think patients will ultimately } \\
\text { benefit in health and social care if } \\
\text { students learn together. }\end{array}$ & $50(62.5 \%)$ & $30(37.5 \%)$ & $65(81.3 \%)$ & $15(18.8 \%)$ & $72(90 \%)$ & $8(10 \%)$ \\
\hline 6. & $\begin{array}{l}\text { Is it important to be taught } \\
\text { communication skills with other health } \\
\text { care students? }\end{array}$ & $49(61.3 \%)$ & $31(38.8 \%)$ & $50(62.5 \%)$ & $30(37.5 \%)$ & $78(97.5 \%)$ & $2(2.5 \%)$ \\
\hline 7. & $\begin{array}{l}\text { Is it important to be taught some of the } \\
\text { communication skills that are related } \\
\text { to patients' safety's for all health care } \\
\text { disciplines } \\
\text { together. }\end{array}$ & $54(67.5 \%)$ & $26(32.5 \%)$ & $68(85 \%)$ & $12(15 \%)$ & $79(98.8 \%)$ & $1(1.3 \%)$ \\
\hline 8. & $\begin{array}{l}\text { Are teamwork skills vital for all health } \\
\text { care students? }\end{array}$ & $63(78.8 \%)$ & $17(21.3 \%)$ & $68(85 \%)$ & $12(15 \%)$ & $79(98.8 \%)$ & $1(1.3 \%)$ \\
\hline 9. & $\begin{array}{l}\text { Learning clinical skills together before } \\
\text { qualification will improve the work } \\
\text { environment. }\end{array}$ & $45(56.3 \%)$ & $35(43.8 \%)$ & $59(73.8 \%)$ & $21(26.3 \%)$ & $78(97.5 \%)$ & $2(2.5 \%)$ \\
\hline 10. & $\begin{array}{l}\text { Respecting other health care students } \\
\text { is essential for IPE to be effective. }\end{array}$ & $61(76.3 \%)$ & $19(23.8 \%)$ & $67(83.8 \%)$ & $13(16.3 \%)$ & $77(96.3 \%)$ & $3(3.8 \%)$ \\
\hline 11. & $\begin{array}{l}\text { IPE for all health care disciplines is a } \\
\text { waste of time. }\end{array}$ & $61(76.3 \%)$ & $19(23.8 \%)$ & $49(61.3 \%)$ & $31(38.8 \%)$ & $15(18.8 \%)$ & $65(81.3 \%)$ \\
\hline 12. & $\begin{array}{l}\text { It is not necessary for one health care } \\
\text { discipline to learn } \\
\text { together with other health care } \\
\text { disciplines. }\end{array}$ & $53(66.3 \%)$ & $27(33.8 \%)$ & $51(63.7 \%)$ & $29(36.3 \%)$ & $26(32.5 \%)$ & $54(67.5 \%)$ \\
\hline 13. & $\begin{array}{l}\text { You would welcome the opportunity to } \\
\text { learn clinical skills with other health care } \\
\text { students. }\end{array}$ & $45(56.3 \%)$ & $35(43.8 \%)$ & $59(73.8 \%)$ & $21(26.3 \%)$ & $78(97.5 \%)$ & $2(2.5 \%)$ \\
\hline 14. & $\begin{array}{l}\text { IPE before qualification will help you to } \\
\text { be a better team } \\
\text { worker. }\end{array}$ & $60(75 \%)$ & $20(25 \%)$ & $67(83.8 \%)$ & $13(16.3 \%)$ & $75(93.8 \%)$ & $5(6.3 \%)$ \\
\hline 15. & $\begin{array}{l}\text { Do you think IPE in curriculum will } \\
\text { improve your working efficiency during } \\
\text { clinical practice and your professional } \\
\text { career? }\end{array}$ & $43(53.8 \%)$ & $37(46.3 \%)$ & $69(86.3 \%)$ & $11(13.8 \%)$ & $80(100 \%)$ & 0 \\
\hline
\end{tabular}

Table 1: Comparison awareness across disciplines. 
Citation: Renuka S, Gheena S (2016) A Questionnaire Based Study on Awareness of Students in Internship Training or Final Year Across 3 Disciplines Regarding Inter-Professional Educcation - A Descriptive Cross Sectional Study. J Health Educ Res Dev 4: 191. doi: 10.4172/23805439.1000191

professional students $(\mathrm{p}<0.001)$ and $62.5 \%$ medical, $81.3 \%$ dental and $90 \%$ nursing students think that patients will be benefited from effective treatment if the students learn together $(\mathrm{p}<0.001)$. In comparison between year of study, $74.4 \%$ interns and $79.6 \%$ final years thinks that it is important to be taught the communication skills together $(\mathrm{p}=0.357)$ and $64.1 \%$ interns, $78.4 \%$ final year feels that the communication skills should be related to patients safety $(\mathrm{p}=0.018)$. Thereby, $51.3 \%$ interns and $49.4 \%$ final year students thinks that patients will be benefited more because of IPE training $(\mathrm{p}=0.783)$. Among medical professionals, $50 \%$ interns and $68 \%$ final year thinks that learning communication skills together with other professionals is essential $(p=0.110)$ and $66.7 \%$ interns and $68 \%$ final year states that the communication skills should be related to patients safety $(p=0.902)$ and $56.7 \%$ interns, $66 \%$ final year feels that patients will be benefited because of IPE $(p=0.404)$. On comparing year of study between dental professionals, $72.9 \%$ interns, $46.9 \%$ final year students and $85.4 \%$ interns, $84.4 \%$ final years and $85.4 \%$ interns, $75 \%$ final year feels that learning communication skills together with other professionals is essential $(\mathrm{p}=0.018)$, the communication skills should be related to patients safety $(\mathrm{p}=0.898)$, patients will be benefited because of IPE $(\mathrm{p}=0.242)$ respectively. Among Interns, $64.1 \%$ medical and dental $(\mathrm{p}=0.040), 78.2 \%$ medical and dental $(\mathrm{p}=0.051), 74.4 \%$ medical and dental $(\mathrm{p}=0.005)$ feels that learning communication skills together with other professionals is important, the communication skills should be related to patients safety, patients will be benefited because of IPE respectively. Among final years, only maximum of $97.5 \%$ nursing students feels learning communication skills together with other professionals is essential $(p<0.001)$ than other professionals, maximum of $98.8 \%$ nursing students thinks that the communication skills should be related to patients safety $(\mathrm{p}<0.001)$ than other professionals and $90 \%$ of nursing students feels that patients will be benefited because of IPE ( $p=0.003$ ) but only $66 \%$ from medical and $75 \%$ from dental students.

Some of the students have a negative opinion on inter-professional Educcation. From the analysis, 63\% medical, 63.7\% dental and 32.5\% nursing students feels that it is not necessary for the professionals to learn together $(p<0.001)$ and $52.1 \%$ from medical, dental and nursing students feels that IPE training is a waste of time $(\mathrm{p}<0.001)$ and $50 \%$ of professionals thinks that it is difficult to adjust with other professionals during IPE training $(p=0.259)$. Comparison between interns and final year shows that $65.4 \%$ interns and $48.8 \%$ final year, $67.9 \%$ interns and $44.4 \%$ final year, $51.3 \%$ interns and $49.4 \%$ final year feels that IPE it is not necessary for the professionals to learn together $(p=0.016)$, IPE training is a waste of time ( $\mathrm{p}=0.001)$ and it is difficult to manage with other professionals during IPE training $(\mathrm{p}=0.783)$ respectively. Among medical professionals, $70 \%$ Interns and $64 \%$ final year, $80 \%$ interns and $74 \%$ final year, $56.7 \%$ interns and 52\% final years feels that IPE it is not necessary for the professionals to learn together $(p=0.0583)$, IPE training is a waste of time ( $\mathrm{p}=0.542)$ and it is difficult to manage with other professionals during IPE training $(\mathrm{p}=0.685)$ respectively. Among dental professionals, $63.7 \%$ interns and final year, $61.3 \%$ interns and final year and $47.9 \%$ interns and $34.4 \%$ final year feels that IPE is not necessary $(p=0.776)$, is a waste of time $(p=0.851)$ and it is difficult to manage to learn with other health care disciplines $(\mathrm{p}=0.230)$. On comparing proportions between interns and final year, $65.4 \%$ medical and dental interns $(\mathrm{p}=0.498)$ and $48.8 \%$ from medical, dental and nursing final year $(p<0.001), 67.9 \%$ medical and dental interns $(\mathrm{p}=0.071)$ and $44.4 \%$ from medical, dental and nursing final year $(p<0.001), 51.3 \%$ medical and dental interns $(p=0.452)$ and $49.4 \%$ from medical, dental and nursing final year $(p=0.163) .87 .5 \%$ of the population think that team work skills plays vital role among health care disciplines. In that population, $78.8 \%$ from medical, $85 \%$ from dental and $98.8 \%$ from nursing states that team work is essential in health care professionals $(\mathrm{p}<0.001)$ and $75 \%$ from medical, $83.8 \%$ from dental and $93.8 \%$ from nursing think that IPE will help students to be a better team worker $(p=0.005)$. On comparing the year of study among professionals, $79.5 \%$ and $91.4 \%$ interns felt that team work will play important role in health care ( $\mathrm{p}=0.009$ ). $83.3 \%$ and $84.6 \%$ final year students feels that IPE will help students to be a better team worker ( $\mathrm{p}=0.806$ ). Among medical professionals, $70 \%$ interns and $84 \%$ final year $(\mathrm{p}=0.138), 66.7 \%$ interns and $80 \%$ final year $(\mathrm{p}=0.182)$ feels that team work skills plays vital role among health care disciplines and IPE will help students to be a better team worker. Among dental professionals, $85.4 \%$ interns and $84.4 \%$ final year $(p=0.898), 93.8 \%$ interns and $68.8 \%$ final years $(p=0.003)$ believe that team work skills plays vital role among health care disciplines and IPE will help students to be a better team worker. Among interns, $79.5 \%$ from medical and dental feels that team work skills plays vital role among health care disciplines $(\mathrm{p}=0.101)$ and $83.3 \%$ medical and dental feels that will help students to be a better team worker $(p=0.002)$. Among final years, 91.4\% from medical, dental and nursing students feels that team work will play important role in health care $(\mathrm{p}=0.004)$ and $84.6 \%$ medical, dental and nursing students feels that will help students to be a better team worker $(\mathrm{p}=0.002)$.

Respecting other health care professionals is essential for IPE to be effective. In the population of $240,85.4 \%$ students feels that respecting other disciplines make inter-professional training more effective. Among $85.4 \%$ students, $76.3 \%$ are from medical, $83.8 \%$ are from dental and $96.3 \%$ from nursing feels that respecting other disciplines make inter-professional training to be effective $(\mathrm{p}=0.001)$. In comparison between years of study, $85.9 \%$ interns and $85.2 \%$ final year thinks that IPE training will be effective when the professionals were respectful to each other $(\mathrm{p}=0.884)$. Among medical profession, $80 \%$ from interns and $74 \%$ final years felt that respecting other disciplines make interprofessional training to be effective $(\mathrm{p}=0.542)$. Among dental profession, $89.6 \%$ from interns and $75 \%$ final years thinks that respecting other disciplines renders inter-professional training to be effective $(\mathrm{p}=0.083)$. Among interns, $80 \%$ from medical, $89.6 \%$ from dental thinks that IPE training will be effective when the professionals were respectful to each other ( $\mathrm{p}=0.237$ ). Among final years, $74 \%$ are from medical, $75 \%$ from dental and $96.3 \%$ from nursing feels that respecting other disciplines make inter-professional training to be effective $(p<0.001)$.

In the population of $240,56.3 \%$ from medical, $73.8 \%$ from dental and $97.5 \%$ from nursing states that learning clinical skills together will help in improving working environment $(p<0.001)$ and $53.8 \%$ from medical, $86.3 \%$ from dental and $100 \%$ from nursing thinks that IPE in curriculum will help to improve working efficiency $(\mathrm{p}<0.001)$. On comparing the year of study among professionals, $70.5 \%(\mathrm{p}=0.182)$, 83.3\% ( $\mathrm{p}=0.806$ ) interns and $78.4 \%$ and $84.6 \%$ final year students felt that learning skills will help to improve work environment and IPE in curriculum will improve working efficiency respectively. Among medical professionals, $50 \%$ interns and $60 \%$ final year ( $\mathrm{p}=0.383$ ), $60 \%$ interns and $50 \%$ final year $(\mathrm{p}=0.385)$ feels that learning clinical skills together with other professionals will improve work environment and IPE in curriculum will help to increase work efficiency. Among dental professionals, $83.3 \%$ interns and $59.4 \%$ final year $(p=0.017)$ $93.8 \%$ interns and $75 \%$ final years $(\mathrm{p}=0.017)$ believe that learning skills will help to improve work environment and IPE in curriculum will improve working efficiency respectively. Among interns, $70.5 \%$ from medical and dental feels that learning clinical skills together with other professionals will improve work environment $(\mathrm{p}=0.002)$ and $80.8 \%$ 
Citation: Renuka S, Gheena S (2016) A Questionnaire Based Study on Awareness of Students in Internship Training or Final Year Across 3 Disciplines Regarding Inter-Professional Educcation - A Descriptive Cross Sectional Study. J Health Educ Res Dev 4: 191. doi: 10.4172/23805439.1000191

medical and dental feels that IPE in curriculum will improve working efficiency $(\mathrm{p}<0.001)$. Among final years, $78.4 \%$ from medical, dental and nursing students feels that learning clinical skills together with other professionals will improve work environment $(\mathrm{p}<0.001)$ and $79.6 \%$ medical, dental and nursing students feels that inter-professional Educcation in curriculum will increase working efficiency $(\mathrm{p}<0.001)$.

According to this analysis, the awareness about and willingness to participate in IPE among students is discussed. In the population of $240,75.8 \%$ students were interested to learn clinical skills with other health care disciplines. Among 75.8\% students, 56.3\% from medical, $73.8 \%$ from dental and $97.5 \%$ from nursing students were interested in active learning about clinical skills with other health care students $(\mathrm{p}<0.001)$. In comparison between years of study, $73.1 \%$ interns and $77.2 \%$ final year feels that they are interested in IPE training $(\mathrm{p}=0.489)$. Among medical profession, $63.3 \%$ from interns and $52 \%$ final years are interested in IPE training $(\mathrm{p}=0.323)$. Among dental profession, $79.2 \%$ from interns and $65.6 \%$ final years were interested in active learning about clinical skills with other health care students ( $\mathrm{p}=0.177$ ). Among interns, $63.3 \%$ from medical, $79.2 \%$ from dental were interested in active learning about clinical skills with other health care students $(\mathrm{p}=0.125)$. Among final years, 52\% from medical, 65.6\% from dental and $97.5 \%$ from nursing students are interested in IPE training $(\mathrm{p}<0.001)$.

All data are collected then compared statistically and are tabulated in Tables 1-5 respectively. Graph 1 shows the differences between the participants from medical, dental and nursing students is significant according to chi-square test $(\mathrm{p}<0.05)$.

\section{Discussion}

This study provides the awareness about Inter professional Educcation among students of various professions such as medical, dental and nursing during their final year and internship training. The present results showed that the students are aware to a certain extent about the importance of inter professional Educcation but still some of the students are sceptical about the necessity of IPE in their curriculum. In a recent study by Norgaard et al. they found that inter professional Educcation will improve the communication between different professionals as well as between professional and the patients. Their result states that before training, clinicians were less confident in communication with other professionals and patients. The improvement in communication was evident in inter professional communication than in intra-professional communication and the communication is much better after finishing the IPE training and more pronounced immediately as well as after 6 months from the training [7]. The most common barrier to IPE is the already overloaded curriculum. A recent survey by Mary et al. states that only minimal formal inter professional activities were conducted in the health care student's curriculum at the seven institutions was investigated. The researchers believe that IPE training among professionals' results in better delivery of health care which is safe, more effective and cost effective. For successful IPE training there must be commitment from both administration and faculties [8].

A recent study by Fallatah et al. states that only $11.4 \%$ knew the meaning of IPE and $88.6 \%$ had no idea what IPE was among 107 participants. According to our study, Most of the students were not aware about inter-professional Educcation initially. $84.2 \%$ students

\begin{tabular}{|c|c|c|c|c|c|}
\hline & & \multicolumn{4}{|c|}{ Medical, Dental and Nursing Professions } \\
\hline & & \multicolumn{2}{|c|}{ Interns } & \multicolumn{2}{|c|}{ Final year } \\
\hline & & Yes & No & Yes & No \\
\hline 1. & Are you aware about Inter-professional Educcation (IPE) & $69(88.5 \%)$ & $9(11.5 \%)$ & $133(82.1 \%)$ & $29(17.9 \%)$ \\
\hline 2. & Do you think IPE is essential in curriculum? & $62(79.5 \%)$ & $16(20.5 \%)$ & $129(79.6 \%)$ & $33(20.4 \%)$ \\
\hline 3. & Do you think that IPE is important during internship & $66(84.6 \%)$ & $12(15.4 \%)$ & $147(90.7 \%)$ & $15(9.3 \%)$ \\
\hline 4. & $\begin{array}{l}\text { Do you think learning with other health care students would } \\
\text { be difficult to manage? }\end{array}$ & $40(51.3 \%)$ & $38(48.7 \%)$ & $80(49.4 \%)$ & $82(50.6 \%)$ \\
\hline 5. & $\begin{array}{l}\text { Do you think patients will ultimately benefit in health and } \\
\text { social care if students learn together. }\end{array}$ & $58(74.4 \%)$ & $20(25.6 \%)$ & $129(79.6 \%)$ & $33(20.4 \%)$ \\
\hline 6. & $\begin{array}{l}\text { Is it important to be taught communication skills with other } \\
\text { health care students? }\end{array}$ & $50(64.1 \%)$ & $28(35.9 \%)$ & $127(78.4 \%)$ & $35(21.6 \%)$ \\
\hline 7. & $\begin{array}{l}\text { Is it important to be taught some of the communication } \\
\text { skills that are related to patients' safety's for all health care } \\
\text { disciplines } \\
\text { together. }\end{array}$ & $61(78.2 \%)$ & $17(21.8 \%)$ & $140(86.4 \%)$ & $22(13.6 \%)$ \\
\hline 8. & Are teamwork skills vital for all health care students? & $62(79.5 \%)$ & $16(20.5 \%)$ & $148(91.4 \%)$ & $14(8.6 \%)$ \\
\hline & $\begin{array}{l}\text { Learning clinical skills together before qualification will } \\
\text { improve the work environment. }\end{array}$ & $55(70.5 \%)$ & $23(29.5 \%)$ & $127(78.4 \%)$ & $35(21.6 \%)$ \\
\hline & $\begin{array}{l}\text { Respecting other health care students is essential for IPE } \\
\text { to be effective. }\end{array}$ & $67(85.9 \%)$ & $11(14.1 \%)$ & $138(85.2 \%)$ & $24(14.8 \%)$ \\
\hline 11. & IPE for all health care disciplines is a waste of time. & $53(67.9 \%)$ & $25(32.1 \%)$ & $72(44.4 \%)$ & $90(55.6 \%)$ \\
\hline & $\begin{array}{l}\text { It is not necessary for one health care discipline to learn } \\
\text { together with other health care disciplines. }\end{array}$ & $51(65.4 \%)$ & $27(34.6 \%)$ & $79(48.8 \%)$ & $83(51.2 \%)$ \\
\hline & $\begin{array}{l}\text { You would welcome the opportunity to learn clinical skills } \\
\text { with other health care students. }\end{array}$ & $57(73.1 \%)$ & $21(26.9 \%)$ & $125(77.2 \%)$ & $37(22.8 \%)$ \\
\hline & $\begin{array}{l}\text { IPE before qualification will help you to be a better team } \\
\text { worker. }\end{array}$ & $65(83.3 \%)$ & $13(16.7 \%)$ & $137(84.6 \%)$ & $25(15.4 \%)$ \\
\hline & $\begin{array}{l}\text { Do you think IPE in curriculum will improve your working } \\
\text { efficiency during clinical practice and your professional } \\
\text { career? }\end{array}$ & $63(80.8 \%)$ & $15(19.2 \%)$ & $129(79.6 \%)$ & $33(20.4 \%)$ \\
\hline
\end{tabular}

Table 2: Comparison between year of study across disciplines. 
Citation: Renuka S, Gheena S (2016) A Questionnaire Based Study on Awareness of Students in Internship Training or Final Year Across 3 Disciplines Regarding Inter-Professional Educcation - A Descriptive Cross Sectional Study. J Health Educ Res Dev 4: 191. doi: 10.4172/23805439.1000191

Page 5 of 7

\begin{tabular}{|c|c|c|c|c|c|}
\hline & & \multicolumn{4}{|c|}{ Comparison between Medical \& Dental professionals respectively } \\
\hline & & \multicolumn{2}{|c|}{ Interns } & \multicolumn{2}{|c|}{ Final year } \\
\hline & & Yes & No & Yes & No \\
\hline & $\begin{array}{l}\text { Are you aware about Inter-professional Educcation } \\
\text { (IPE) }\end{array}$ & $25(83.3 \%) \& 44(91.7 \%)$ & $5(16.7 \%) \& 4(8.3 \%)$ & $45(90 \%) \& 25(78.1 \%)$ & $5(10 \%) \& 7(21.9 \%)$ \\
\hline 2. & Do you think IPE is essential in curriculum? & $22(73.3 \%) \& 40(83.3 \%)$ & $8(26.7 \%) \& 8(16.7 \%)$ & $29(58 \%) \& 20(62.5 \%)$ & $21(42 \%) \& 12(37.5 \%)$ \\
\hline 3. & Do you think that IPE is important during internship & $26(86.7 \%) \& 40(83.3 \%)$ & $4(13.3 \%) \& 8(16.7 \%)$ & $41(82 \%) \& 27(84.4 \%)$ & $9(18 \%) \& 5(15.6 \%)$ \\
\hline 4. & $\begin{array}{l}\text { Do you think learning with other health care students } \\
\text { would be difficult to manage? }\end{array}$ & $17(56.7 \%) \& 23(47.9 \%)$ & $13(43.3 \%) \& 25(52.1 \%)$ & $26(52 \%) \& 11(34.4 \%)$ & $24(48 \%) \& 21(65.6 \%)$ \\
\hline 5. & $\begin{array}{l}\text { Do you think patients will ultimately benefit in health and } \\
\text { social care if students learn together. }\end{array}$ & $17(56.7 \%) \& 41(85.4 \%)$ & $13(43.3 \%) \& 7(14.6 \%)$ & $33(66 \%) \& 24(75 \%)$ & $17(34 \%) \& 8(25 \%)$ \\
\hline 6. & $\begin{array}{l}\text { Is it important to be taught communication skills with } \\
\text { other health care students? }\end{array}$ & $15(50 \%) \& 35(72.9 \%)$ & $15(50 \%) \& 13(27.1 \%)$ & $34(68 \%) \& 15(46.9 \%)$ & $16(32 \%) \& 17(53.1 \%)$ \\
\hline 7. & $\begin{array}{l}\text { Is it important to be taught some of the communication } \\
\text { skills that are related to patients' safety's for all health } \\
\text { care disciplines } \\
\text { together. }\end{array}$ & $20(66.7 \%) \& 41(85.4 \%)$ & $10(33.3 \%) \& 7(14.6 \%)$ & $34(68 \%) \& 27(84.4 \%)$ & $16(32 \%) \& 5(15.6 \%)$ \\
\hline 8. & Are teamwork skills vital for all health care students? & $21(70 \%) \& 41(85.4 \%)$ & $9(30 \%) \& 7(14.6 \%)$ & $42(84 \%) \& 27(84.4 \%)$ & $8(16 \%) \& 5(15.6 \%)$ \\
\hline 9. & $\begin{array}{l}\text { Learning clinical skills together before qualification will } \\
\text { improve the work environment. }\end{array}$ & $15(50 \%) \& 40(83.3 \%)$ & $15(50 \%) \& 8(16.7 \%)$ & $30(60 \%) \& 19(59.4 \%)$ & $20(40 \%) \& 13(40.6 \%)$ \\
\hline 10. & $\begin{array}{l}\text { Respecting other health care students is essential for } \\
\text { IPE to be effective. }\end{array}$ & $24(80 \%) \& 43(89.6 \%)$ & $6(20 \%) \& 5(10.4 \%)$ & $37(74 \%) \& 24(75 \%)$ & $13(26 \%) \& 8(25 \%)$ \\
\hline 11. & IPE for all health care disciplines is a waste of time. & $24(80 \%) \& 29(60.4 \%)$ & $6(20 \%) \& 19(39.6 \%)$ & $37(74 \%) \& 20(62.5 \%)$ & $13(26 \%) \& 12(37.5 \%)$ \\
\hline & $\begin{array}{l}\text { It is not necessary for one health care discipline to learn } \\
\text { together with other health care disciplines. }\end{array}$ & $21(70 \%) \& 30(62.5 \%)$ & $9(30 \%) \& 18(37.5 \%)$ & $32(64 \%) \& 21(65.6 \%)$ & $18(36 \%) \& 11(34.4 \%)$ \\
\hline 13. & $\begin{array}{l}\text { You would welcome the opportunity to learn clinical } \\
\text { skills with other health care students. }\end{array}$ & $19(63.3 \%) \& 38(79.2 \%)$ & $11(36.7 \%) \& 10(20.8 \%)$ & $26(52 \%) \& 21(65.6 \%)$ & $24(48 \%) \& 11(34.4 \%)$ \\
\hline & $\begin{array}{l}\text { IPE before qualification will help you to be a better team } \\
\text { worker. }\end{array}$ & $20(66.7 \%) \& 45(93.8 \%)$ & $10(33.3 \%) \& 3(6.3 \%)$ & $40(80 \%) \& 22(68.8 \%)$ & $10(20 \%) \& 10(31.3 \%)$ \\
\hline & $\begin{array}{l}\text { Do you think IPE in curriculum will improve your } \\
\text { working efficiency during clinical practice and your } \\
\text { professional career? }\end{array}$ & $18(60 \%) \& 45(93.8 \%)$ & $12(40 \%) \& 3(6.3 \%)$ & $25(50 \%) \& 24(75 \%)$ & $25(50 \%) \& 8(25 \%)$ \\
\hline
\end{tabular}

Table 3: Comparison within interns and final year between medical and dental professionals.

\begin{tabular}{|c|c|c|c|c|c|}
\hline & & \multicolumn{2}{|c|}{ Medical } & \multicolumn{2}{|c|}{ Dental } \\
\hline & & Yes & No & Yes & No \\
\hline & $\begin{array}{l}\text { Are you aware about Inter-professional Educcation } \\
\text { (IPE) }\end{array}$ & $25(83.3 \%)$ & $5(16.7 \%)$ & $44(91.7 \%)$ & $4(8.3 \%)$ \\
\hline 2. & Do you think IPE is essential in curriculum? & $22(73.3 \%)$ & $8(26.7 \%)$ & $40(83.3 \%)$ & $8(16.7 \%)$ \\
\hline 3. & Do you think that IPE is important during internship & $26(86.7 \%)$ & $4(13.3 \%)$ & $40(83.3 \%)$ & $8(16.7 \%)$ \\
\hline 4. & $\begin{array}{l}\text { Do you think learning with other health care students } \\
\text { would be difficult to manage? }\end{array}$ & $17(56.7 \%)$ & $13(43.3 \%)$ & $23(47.9 \%)$ & $25(52.1 \%)$ \\
\hline 5. & $\begin{array}{l}\text { Do you think patients will ultimately benefit in health } \\
\text { and social care if students learn together. }\end{array}$ & $17(56.7 \%)$ & $13(43.3 \%)$ & $41(85.4 \%)$ & $7(14.6 \%)$ \\
\hline 6. & $\begin{array}{l}\text { Is it important to be taught communication skills with } \\
\text { other health care students? }\end{array}$ & $15(50 \%)$ & $15(50 \%)$ & $35(72.9 \%)$ & $13(27.1 \%)$ \\
\hline 7. & $\begin{array}{l}\text { Is it important to be taught some of the communication } \\
\text { skills that are related to patients' safety's for all health } \\
\text { care disciplines } \\
\text { together. }\end{array}$ & $20(66.7 \%)$ & $10(33.3 \%)$ & $41(85.4 \%)$ & $7(14.6 \%)$ \\
\hline 8. & Are teamwork skills vital for all health care students? & $21(70 \%)$ & $9(30 \%)$ & $41(85.4 \%)$ & $7(14.6 \%)$ \\
\hline 9. & $\begin{array}{l}\text { Learning clinical skills together before qualification will } \\
\text { improve the work environment. }\end{array}$ & $15(50 \%)$ & $15(50 \%)$ & $40(83.3 \%)$ & $8(16.7 \%)$ \\
\hline 10. & $\begin{array}{l}\text { Respecting other health care students is essential for } \\
\text { IPE to be effective. }\end{array}$ & $24(80 \%)$ & $6(20 \%)$ & $43(89.6 \%)$ & $5(10.4 \%)$ \\
\hline 11. & IPE for all health care disciplines is a waste of time. & $24(80 \%)$ & $6(20 \%)$ & $29(60.4 \%)$ & 19(39.6\%) \\
\hline & $\begin{array}{l}\text { It is not necessary for one health care discipline to learn } \\
\text { together with other health care disciplines. }\end{array}$ & $21(70 \%)$ & $9(30 \%)$ & $30(62.5 \%)$ & $18(37.5 \%)$ \\
\hline & $\begin{array}{l}\text { You would welcome the opportunity to learn clinical } \\
\text { skills with other health care students. }\end{array}$ & $19(63.3 \%)$ & $11(36.7 \%)$ & $38(79.2 \%)$ & $10(20.8 \%)$ \\
\hline 14. & $\begin{array}{l}\text { IPE before qualification will help you to be a better team } \\
\text { worker. }\end{array}$ & $20(66.7 \%)$ & $10(33.3 \%)$ & $45(93.8 \%)$ & $3(6.3 \%)$ \\
\hline & $\begin{array}{l}\text { Do you think IPE in curriculum will improve your } \\
\text { working efficiency during clinical practice and your } \\
\text { professional career? }\end{array}$ & $18(60 \%)$ & $12(40 \%)$ & $45(93.8 \%)$ & $3(6.3 \%)$ \\
\hline
\end{tabular}

Table 4: Comparison on proportions between professionals among Interns. 
Citation: Renuka S, Gheena S (2016) A Questionnaire Based Study on Awareness of Students in Internship Training or Final Year Across 3 Disciplines Regarding Inter-Professional Educcation - A Descriptive Cross Sectional Study. J Health Educ Res Dev 4: 191. doi: 10.4172/23805439.1000191

Page 6 of 7

\begin{tabular}{|c|c|c|c|c|c|c|}
\hline \multirow{3}{*}{1.} & \multicolumn{6}{|c|}{ Final year } \\
\hline & \multicolumn{2}{|c|}{ Medical } & \multicolumn{2}{|c|}{ Dental } & \multicolumn{2}{|c|}{ Nursing } \\
\hline & Yes & No & Yes & No & Yes & No \\
\hline $\begin{array}{l}\text { 1. Are you aware about Inter-professional } \\
\text { Educcation (IPE) }\end{array}$ & $45(90 \%)$ & $5(10 \%)$ & $25(78.1 \%)$ & $7(21.9 \%)$ & $63(78.8 \%)$ & $17(21.3 \%)$ \\
\hline 2. Do you think IPE is essential in curriculum? & $29(58 \%)$ & $21(42 \%)$ & $20(62.5 \%)$ & $12(37.5 \%)$ & $80(100 \%)$ & 0 \\
\hline $\begin{array}{l}\text { 3. Do you think that IPE is important during } \\
\text { internship }\end{array}$ & $41(82 \%)$ & $9(18 \%)$ & $27(84.4 \%)$ & $5(15.6 \%)$ & 79(98.8\%) & $1(1.3 \%)$ \\
\hline $\begin{array}{l}\text { 4. Do you think learning with other health care } \\
\text { students would be difficult to manage? }\end{array}$ & $26(52 \%)$ & $24(48 \%)$ & $11(34.4 \%)$ & $21(65.6 \%)$ & $43(53.8 \%)$ & $37(46.3 \%)$ \\
\hline $\begin{array}{l}\text { 5. Do you think patients will ultimately benefit in } \\
\text { health and social care if students learn together. }\end{array}$ & $33(66 \%)$ & $17(34 \%)$ & $24(75 \%)$ & $8(25 \%)$ & 72(90\%) & $8(10 \%)$ \\
\hline $\begin{array}{l}\text { 6. Is it important to be taught communication skills } \\
\text { with other health care students? }\end{array}$ & $34(68 \%)$ & $16(32 \%)$ & $15(46.9 \%)$ & $17(53.1 \%)$ & $78(97.5 \%)$ & $2(2.5 \%)$ \\
\hline $\begin{array}{l}\text { 7. Is it important to be taught some of the } \\
\text { communication skills that are related to patients' } \\
\text { safety's for all health care disciplines } \\
\text { together. }\end{array}$ & $34(68 \%)$ & $16(32 \%)$ & $27(84.4 \%)$ & $5(15.6 \%)$ & 79(98.8\%) & $1(1.3 \%)$ \\
\hline $\begin{array}{l}\text { 8. Are teamwork skills vital for all health care } \\
\text { students? }\end{array}$ & $42(84 \%)$ & $8(16 \%)$ & $27(84.4 \%)$ & $5(15.6 \%)$ & $79(98.8 \%)$ & $1(1.3 \%)$ \\
\hline $\begin{array}{l}\text { 9. Learning clinical skills together before } \\
\text { qualification will improve the work environment. }\end{array}$ & $30(60 \%)$ & $20(40 \%)$ & $19(59.4 \%)$ & $13(40.6 \%)$ & $78(97.5 \%)$ & $2(2.5 \%)$ \\
\hline $\begin{array}{l}\text { 10. Respecting other health care students is } \\
\text { essential for IPE to be effective. }\end{array}$ & $37(74 \%)$ & $13(26 \%)$ & $24(75 \%)$ & $8(25 \%)$ & $77(96.3 \%)$ & $3(3.8 \%)$ \\
\hline $\begin{array}{l}\text { 11. IPE for all health care disciplines is a waste of } \\
\text { time. }\end{array}$ & $37(74 \%)$ & $13(26 \%)$ & $20(62.5 \%)$ & $12(37.5 \%)$ & $15(18.8 \%)$ & $65(81.3 \%)$ \\
\hline $\begin{array}{l}\text { 12. It is not necessary for one health care discipline } \\
\text { to learn } \\
\text { together with other health care disciplines. }\end{array}$ & $32(64 \%)$ & $18(36 \%)$ & $21(65.6 \%)$ & 11(34.4\%) & $26(32.5 \%)$ & $54(67.5 \%)$ \\
\hline $\begin{array}{l}\text { 13. You would welcome the opportunity to learn } \\
\text { clinical skills with other health care students. }\end{array}$ & $26(52 \%)$ & $24(48 \%)$ & 21(65.6\%) & $11(34.4 \%)$ & $78(97.5 \%)$ & $2(2.5 \%)$ \\
\hline $\begin{array}{l}\text { 14. IPE before qualification will help you to be a } \\
\text { better team } \\
\text { worker. }\end{array}$ & $40(80 \%)$ & $10(20 \%)$ & $22(68.8 \%)$ & $10(31.3 \%)$ & $75(93.8 \%)$ & $5(6.3 \%)$ \\
\hline $\begin{array}{l}\text { 15. Do you think IPE in curriculum will improve } \\
\text { your working efficiency during clinical practice } \\
\text { and your professional career? }\end{array}$ & $25(50 \%)$ & $25(50 \%)$ & $24(75 \%)$ & $8(25 \%)$ & $80(100 \%)$ & 0 \\
\hline
\end{tabular}

Table 5: Comparison on proportions between professionals among final year students.

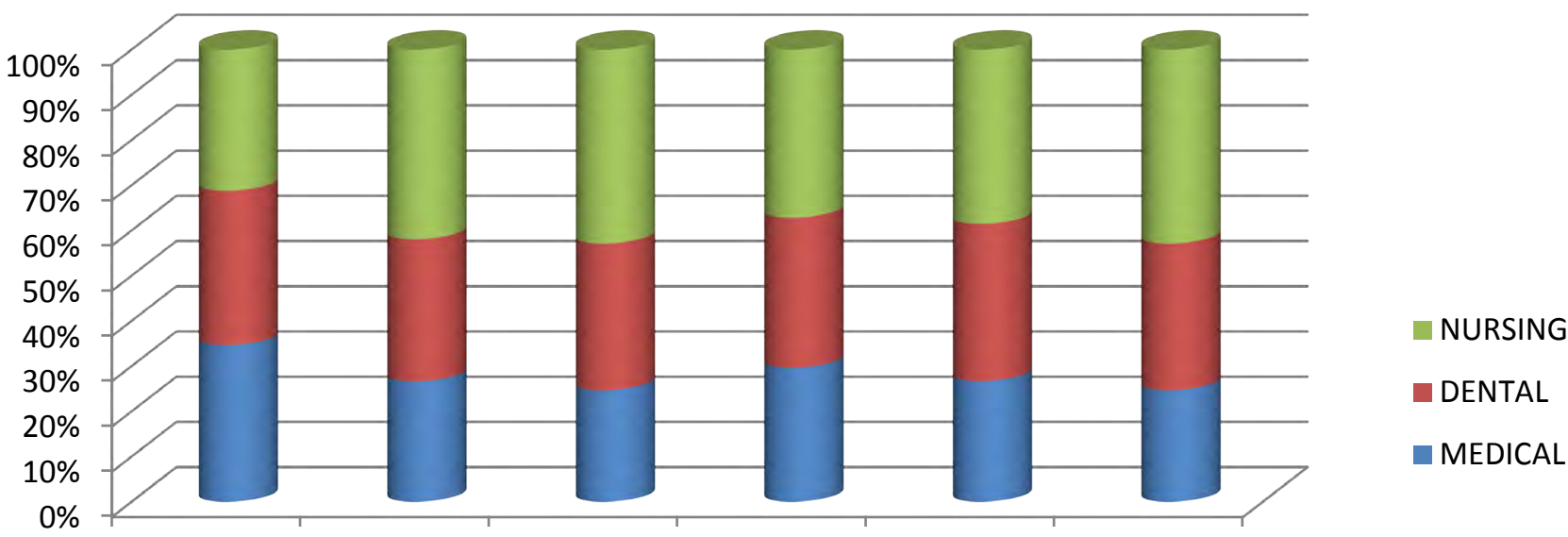

Are you Do you think Learning IPE before Do you think You would aware about IPE is clinical skills qualification patients will welcome the IPE essential in together will help you be benefit by opportunity
curriculum will improve to be a
IPE
to be a
the work better team
participant
environment worker
in IPE

Graph 1: Result of survey about Inter professional Educcation (IPE) among intern and final year students of medical, dental and nursing 
Citation: Renuka S, Gheena S (2016) A Questionnaire Based Study on Awareness of Students in Internship Training or Final Year Across 3 Disciplines Regarding Inter-Professional Educcation - A Descriptive Cross Sectional Study. J Health Educ Res Dev 4: 191. doi: 10.4172/23805439.1000191

were aware about inter professional Educcation and its necessity in total of 240 population from medical, dental and nursing only after explaining about the importance of IPE. According to a study by Fallatah et al. $75 \%$ responded that IPE is important and only $18.5 \%$ from medical, $10 \%$ from nursing state that IPE was waste of time [9]. According to this study, $63.7 \%$ of medical, $75 \%$ of dental and $100 \%$ of nursing students' states that IPE is necessary in curriculum after explanation and $20.4 \%$ from medical and dental students' states that it is not important in curriculum and $52.1 \%$ feels that IPE is a waste of time. According to a study by Fallatah et al. $24.8 \%$ strongly agree that patients will be benefited if the students from different health care professionals learn together. $8.6 \%$ feels that patients will not be benefited if the professionals learn together [9]. According to this study, $77.9 \%$ states that patients will be benefited in co-ordinated care and $22 \%$ feels that there is no benefit for the patients if the professionals are together. $73.4 \%$ of students welcome the opportunity to participate in IPE training and $15.3 \%$ were not interested. Based on this study, $75.8 \%$ welcome the opportunity to learn together with other professionals and 24.2\% were not interested. $93.3 \%$ feels that team work skills are vital for all health care students [9]. In this study, only $87.5 \%$ students felt that team work will pay good and effective care for the patients.

Hence, Inter-professional Educcation programs that aim to improve good communication between health care professionals with patients. Hence, there is a need for Educcational programs to improve the communication skills for effective health practices and attitude towards other professionals.

\section{Conclusion}

This study showcases the importance of inter professional Educcation during final year and internship for the students of medical, dental and nursing. Students are not fully familiar with inter professional Educcation, more awareness is required for them to be adept in this regard and to impart effective and proper treatment to their patients. The results of this study will be helpful for the health care schools to conduct more Educcation programs about Inter professional Educcation in the future. Though there was a mixed response in relation to the necessity of IPE, it was in favour of IPE. The importance of IPE in effective communication with patients is also mentioned. Students expressed interest in learning clinical skills alongside other health care disciplines.

\section{References}

1. Centre for the Advancement of Inter Professional Educcation (CAIPE) (1997) Inter professional Educcation - a definition. London: CAIPE Bulletin 13: 19.

2. Vahey DC, Aiken LH, Sloane DM, Clarke SP, Vargas D (2004) Nurse Burn out and Patient Satisfaction. Med Care 42: 57-66.

3. Liakos J, Frigas A, Antypas K, Zikos D, Diomidous M, et al. (2008) Promoting inter professional Educcation in health sector within the European Interprofessional Educcation Network. Int J Med Inform 78: 43-47.

4. Mendez MJ, Armayor NC, Navarlaz MT, Wakefield A (2007) The potential advantages and disadvantages of introducing inter professional Educcation into the health care curricula in Spain. Nurse Educc Today 28: 327-336.

5. Cooper H, Carlisle C, Gibbs T, Watkins C (2001) Developing an evidence base for inter disciplinary learning: A systematic review. J Adv Nurs 35: 228-237.

6. Hall P, Weaver L (2001) Interdisciplinary Educcation and Teamwork: A Long and Winding Road. Med Educc 35: 867-875.

7. Nørgaard B, Ammentorp J, Kofoed P, Kyvik KO (2012) Training improves intercollegial communication. The clinical teacher 9: 173-177.

8. Rafter ME, Pesun IJ, Herren M, Linfante JC, Mina M, et al. (2006) A Preliminary Survey of Inter professional Educcation. J Dent Educc 70: 417-427.

9. Fallatah HI, Jabbad R, Fallatah HK (2015) Inter professional Educcation as a Need: The Perception of Medical, Nursing Students and Graduates of Medical College at King Abdulaziz University. Scientific research 6: 248-254. 